\title{
WATER INFILTRATION IN AN ULTISOL AFTER CULTIVATION OF COMMON BEAN ${ }^{(1)}$
}

\author{
Maria Aparecida do Nascimento dos Santos ${ }^{(2)}$, Elói Panachuki ${ }^{(3)}$, Teodorico Alves \\ Sobrinho $^{(4)}$, Paulo Tarso Sanches de Oliveira ${ }^{(5)}$ \& Dulce Buchala Bicca Rodrigues ${ }^{(5)}$
}

\begin{abstract}
SUMMARY
Water infiltration in the soil is an important hydrological process that occurs at the interface of the soil-atmosphere system; thus, the soil management practice used has a strong influence on this process. The aim of this study was to evaluate water infiltration in the soil and compare equations for estimating the water infiltration rate in an Ultisol after harvesting common bean (Phaseolus vulgaris L.) under simulated rainfall. Field tests with a rainfall simulator were carried out in three soil management systems: minimum tillage (MT), conventional tillage (CT), and no tillage (NT). In NT, four levels of plant residue on the soil surface were evaluated: 0, 3, 6, and $9 \mathrm{t} \mathrm{ha}^{-1}$. The models of Kostiakov-Lewis, Horton, and Philip were used to estimate the infiltration rate. In the MT system, the final infiltration rate was $54 \mathrm{~mm} \mathrm{~h}^{-1}$, whereas in the CT and NT systems with up to $3 \mathrm{t} \mathrm{ha}^{-1}$ of plant residue on the soil surface, the rate was near $17 \mathrm{~mm} \mathrm{~h}^{-1}$. In addition, the results indicated that in the NT system the infiltration rate increased with plant residue coverage greater than $6 \mathrm{t} \mathrm{ha}^{-1}$, i.e., there was a positive correlation between plant cover and the water infiltration rate. The Horton model was the most suitable in representing the water infiltration process in the soil. Therefore, this model can be recommended for estimation of this variable regardless of the soil tillage system used.
\end{abstract}

Index terms: runoff, soil management, rainfall simulator.

(1) Part of the Master's Dissertation of the first author. Received for publication on September 4, 2013 and approved on June 5, 2014.

(2) Master's degree student in Plant Production, Department of Agronomy, Universidade Estadual de Mato Grosso do Sul UEMS. Caixa Postal 25. CEP 79200-000 Aquidauana (MS), Brazil. E-mail: mariaagronomia@gmail.com

(3) Professor, Department of Agronomy, UEMS. Email: eloip@uems.br

(4) Professor, FAENG, Universidade Federal de Mato Grosso do Sul. Caixa Postal 549. CEP 79070-900 Campo Grande (MS), Brazil. E-mail: teodorico.alves@ufms.br

(5) Doctoral student, Department of Hydraulics and Sanitary Engineering, Universidade de São Paulo - USP. Caixa Postal 359. CEP 13566-590 São Carlos (SP), Brazil. E-mail: paulot@sc.usp.br, dulce@sc.usp.br 


\title{
RESUMO: INFILTRAÇÃO DE ÁGUA EM ARGISSOLO VERMELHO, APÓS CULTIVO DE FEIJÃO
}

\begin{abstract}
A infiltração de água no solo é um importante processo hidrológico que ocorre na interface solo-atmosfera; assim, o manejo do solo tem forte influência nesse processo. Este estudo teve por objetivos avaliar a infiltração de água no solo e comparar as equações para estimativa da sua taxa de infiltração de água em Argissolo Vermelho distrófico típico, após a colheita da cultura do feijão (Phaseolus vulgaris L.) sob chuva simulada. Os testes de campo, com uso de simulador de chuvas, foram realizados nos sistemas de manejo do solo: cultivo mínimo (CM), preparo convencional $(P C)$ e plantio direto $(P D)$. No $P D$, foram feitas avaliações sobre quatro níveis de residuo vegetal na superfície do solo: 0, 3, 6 e $9 \mathrm{Mg} \mathrm{ha}^{-1}$. Os modelos de KostiakovLewis, Horton e Philip foram utilizados para estimativa da taxa de infiltração. No CM, a taxa de infiltração final foi de $54 \mathrm{~mm} \mathrm{~h}^{-1}$, enquanto no $\mathrm{PC}$ e no $\mathrm{PD}$, com até $3 \mathrm{Mg} \mathrm{ha}^{-1}$ de resíduo vegetal na superfície, a taxa foi próxima de $17 \mathrm{~mm} \mathrm{~h}^{-1}$. No $P D$, houve aumento na taxa de infiltração com cobertura de resíduo acima de $6 \mathrm{Mg} \mathrm{ha}^{-1}$, ou seja, houve correlação positiva entre cobertura vegetal e taxa de infiltração de água. O modelo de Horton foi o mais adequado para representar o comportamento da taxa de infiltração de água no solo, podendo ser recomendado para a estimativa dessa variável independente do sistema de manejo de solo utilizado.
\end{abstract}

Termos de indexação: escoamento superficial, manejo do solo, simulador de chuva.

\section{INTRODUCTION}

Water infiltration in the soil is one of the most important hydrological processes that occurs at the interface of the soil-atmosphere system (Mbagwu, 1995) because it is related to feeding underground water reserves, to water availability to plants, and to the severity of the results of rain torrents that may lead to soil water erosion (Lipiec et al., 2006; Zonta et al., 2012). Assouline (2013) affirms that the complexity of the water infiltration process in the soil is associated with various factors, such as the water supply rate, the time that has passed since the beginning of the rainfall, the chemical composition of the soil and the water, the spatial variability and distribution of the hydraulic properties in the soil profile, the topography, the temperature, and probably additional factors related to soil biology and microbiology.

Conditions at the soil surface and the organization of porosity throughout the profile are among the factors that affect the dynamic of the water infiltration process. Soil tillage operations exercise a temporary effect on infiltration upon leaving the soil with a loose texture, facilitating permeability for water. However, if there is no plant cover, the kinetic energy of the rain is transferred directly to the soil, promoting disaggregation of particles, reduction of the water infiltration rate, and an increase in surface runoff $(\mathrm{Li}$ et al., 2009). According to Panachuki et al. (2006), conventional tillage generally alters the physical conditions of the soil through surface disaggregation, which, after rainfall, favors the appearance of a crust on the surface, and soil compaction below the tilled layer. These factors limit water infiltration and accelerate the erosion process.

Conservationist soil use systems, such as no tillage and minimum tillage, aim at reducing the harmful effects of implements in soil preparation, minimizing their movement, and maintaining greater protection of the soil surface through crop residues. The no-till planting system is a soil management system which is effective in conservation of soil and water resources, protecting the soil from erosion and favoring sustainable agricultural production (Abid \& Lal, 2009). Minimum tillage incorporates fewer crop residues in the soil compared to conventional tillage (ASAE, 1982), increases surface roughness (Bertol et al., 2006; Panachuki et al., 2010) and assists in decompaction of deeper soil layers through the action of the chisel plow, favoring water movement throughout the soil profile (Dallmeyer, 1994; Panachuki et al., 2011).

Water infiltration in the soil may be measured in the field or estimated by mathematical models that may be empirical or theoretical with a physical basis. Empirical models are usually presented in the form of simple equations and provide only an estimate of the accumulated infiltration and of the infiltration rate; they do not provide information in relation to the content and distribution of water in the soil (Rao et al., 2006). Characterization of the variables that affect infiltration is a laborious and time-consuming process. The intensity with which some variables affect the infiltration process has not yet been well defined. Thus, diverse models have been proposed seeking to simplify the study of water infiltration in the soil.

The empirical model usually used in irrigation management is the Kostiakov-Lewis equation, generally used for the estimate of accumulated infiltration, whose parameters do not have their own physical meaning and are estimated from experimental data (Assouline, 2013). In hydrology studies, the Horton equation is among the empirical models most used to express water infiltration in the soil in relation to the time of occurrence of rainfall for 
a determined soil (Akan, 1992). In this model, reduction in the infiltration rate over time is strongly controlled by factors that operate on the soil surface, such as surface sealing, due to the impact of raindrops and the phenomena of soil expansion and contraction. Another highly used model, as described by Assouline (2013), is the theoretical equation of Philip, which has a strong physical basis, with great dependence on soil physical properties. Infiltration is considered, by this model, as a process related to water sorption by the soil, which implies less importance being given to gravitational activity in comparison to the other models evaluated, especially in the initial stages of infiltration when the soil profile has less moisture.

The aim of the study was to evaluate water infiltration in the soil and verify the suitability of the equations of Kostiakov-Lewis, Horton, and Philip in estimating the water infiltration rate in an Ultisol (Argissolo Vermelho distrófico típico) subjected to different soil tillage systems after cultivation of common bean (Phaseolus vulgaris L.).

\section{MATERIALS AND METHODS}

\section{Description of the experimental area and of the treatments}

The study was carried out in Aquidauana, MS, Brazil, latitude $20^{\circ} 28^{\prime} \mathrm{S}$ and longitude $55^{\circ} 40^{\prime} \mathrm{W}$, at a mean altitude of $191 \mathrm{~m}$. The region lies within the Cerrado-Pantanal Ecotone (tropical savanna-tropical wetland ecotone) and has a climate classified as hot sub-humid tropical, with mean annual rainfall of $1,400 \mathrm{~mm}$ and mean annual temperature of $24^{\circ} \mathrm{C}$.

The soil is classified as an Ultisol (Argissolo Vermelho distrófico típico) with a sandy loam texture and mean values of 750,130 , and $120 \mathrm{~g} \mathrm{~kg}^{-1}$ of sand, silt, and clay, respectively, in the A horizon. The Bt Horizon occurs in the interval from 0.50 to $1.09 \mathrm{~m}$ depth, with particle size corresponding to 597,136 , and $267 \mathrm{~g} \mathrm{~kg}^{-1}$ of sand, silt, and clay, respectively. The location has a flat to slightly rolling topography with a mean slope of $0.03 \mathrm{~m} \mathrm{~m}^{-1}$. In the last six years, it was planted to soybean, corn, common bean, and pearl millet in crop rotation. Common bean (Phaseolus vulgaris L.) was grown for this study, with 16 plants per meter in the plant row and between-row spacing of $0.45 \mathrm{~m}$. Mean grain yield was $2.52 \mathrm{Mg} \mathrm{ha}^{-1}$ and mean common bean plant residue (leaves, stem, and pods) was $2.9 \mathrm{Mg} \mathrm{ha}^{-1}$ in the experimental area.

For analysis of soil bulk density, macroporosity, and total porosity, soil samples were taken at the depths of 0.00-0.10 and 0.10-0.20 $\mathrm{m}$ through soil sample rings with a volume of $0.10 \mathrm{dm}^{3}$, according to Embrapa (1997).

For evaluation of water infiltration in the soil, the rain simulator developed by Alves Sobrinho et al.
(2008) was used, equipped with Veejet 80.150 nozzles placed at $2.30 \mathrm{~m}$ from the soil. In the experimental plots, with dimensions of $1 \mathrm{~m}$ length in the direction of the slope by $0.7 \mathrm{~m}$ width, simulated rains were applied with intensity planned for $60 \mathrm{~mm} \mathrm{~h}^{-1}$, which has been adopted in studies of this nature (Carvalho et al., 2002; Vahabi \& Nikkami, 2008; Panachuki et al., 2011; Huang et al., 2013).

The simulated rain tests in the field were carried out in three soil tillage systems: minimum tillage performed with one pass with a chisel plow with six shanks at a distance of $0.25 \mathrm{~m}$, reaching a depth of $0.30 \mathrm{~m}$ (MT); conventional tillage which consisted of one pass with a plow disk with 20 disks of $0.58 \mathrm{~m}$ diameter reaching $0.20 \mathrm{~m}$ depth, followed by one pass with a leveling disk harrow with 32 disks of $0.43 \mathrm{~m}$ diameter reaching $0.08 \mathrm{~m}$ depth $(\mathrm{CT})$; and no-till planting, where the treatments were set up without mechanically turning over the soil (NT). In the NT, evaluations were made of soil surface roughness and of water infiltration at four rates of plant residue on the soil surface, characterized in the following manner: without plant residue (NT0), $3 \mathrm{Mg} \mathrm{ha}^{-1}$ of residue (NT3), $6 \mathrm{Mg} \mathrm{ha}^{-1}$ of residue (NT6), and $9 \mathrm{Mg} \mathrm{ha}^{-1}$ of residue (NT9). Thus, the experiment consisted of six different treatments. In the treatments under no-till, after common bean harvest, the plant residues were collected and then dried in a laboratory oven at $65^{\circ} \mathrm{C}$ and redistributed in the plots according to the level of residue planned for each treatment.

With the aim of homogenizing soil moisture, the experimental plots were pre-soaked approximately $24 \mathrm{~h}$ before the beginning of the tests (Cogo et al., 1984).

For random evaluation of soil surface roughness (RR), the height of the microrelief of the soil was estimated through the use of a pin microrelief meter connected to a digital camera, as described by Panachuki et al. (2010). The RR index was calculated as the standard deviation of the values of readings of the heights of the microrelief of the soil, according to Kamphorst et al. (2000).

The time of beginning of surface runoff of water was considered as being the time interval between the beginning of application of simulated rain and the beginning of runoff, while the duration of the rain was $1 \mathrm{~h}$ after the runoff began (Panachuki et al., 2006).

Kinetic energy of the rain was calculated according to Alves Sobrinho et al. (2001), using the program EnerChuva.

During the rainfall tests, samples of the volume of surface runoff were collected for $1 \mathrm{~min}$ and in periodic intervals of $1 \mathrm{~min}$, for a total of 31 samples in each trial with the simulator. The runoff depth was obtained by the ratio between the volume of runoff water and the area of the plot. The water depth infiltrated was calculated by the difference between the water depth applied by the simulator and the 
surface runoff depth, with this calculation being made every minute. The infiltration rate was obtained by the ratio between the infiltrated water depth and the time interval of collection. The final rate of infiltration was obtained when stabilization of the surface runoff depth was observed (Panachuki et al., 2006).

\section{Statistical analysis}

The treatments were analyzed according to a randomized block design with four replications, for a total of 24 simulated rain tests. The data related to the physical properties of the soil and water infiltration in the soil were subjected to analysis of variance, and the mean values were compared by the Tukey test at $5 \%$.

\section{Models for estimation of the water infiltration rate in the soil}

With the infiltration data, equations were fitted for estimation of the infiltration rate as a function of time, using the models proposed by Kostiakov-Lewis (Equation 1), Horton (Equation 2), and Philip (Equation 3), as described in Assouline (2013):

$$
\begin{aligned}
& i=i_{f}+\alpha k t^{a-1} \\
& i=i_{f}+\left(i_{0}-i_{f}\right) e^{-\beta t} \\
& i=i_{f}+1 / 2 k t^{-0.5}
\end{aligned}
$$

in which $i$ is the infiltration rate, $\mathrm{mm} \mathrm{h}^{-1} ; i_{o}$ is the initial infiltration rate observed, $\mathrm{mm} \mathrm{h}^{-1} ; i_{f}$ is the final infiltration rate, $\mathrm{mm} \mathrm{h}^{-1} ; \alpha, \beta$ and $k$ are the empirical parameters of the models; and $t$ is the time of infiltration, in min.

The empirical parameters of the models were estimated by non-linear regression, Gauss-Newton method, based on infiltration data observed over 60 min of simulated rain. The quality of the fit of the models was verified by statistical indices and graphic comparisons between the mean values observed and those estimated. For performance analysis of the models, combined analysis of diverse indices was carried out, since a model may fit experimental data well by the indicator of the index without the real process under study being well represented. Thus, in addition to the coefficient of determination $\left(R^{2}\right)$, the statistical indices described by Willmott et al. (1985) were applied: the coefficient of residual mass (CRM) (Equation 4), the coefficient of adjustment (CA) (Equation 5), and efficiency (EF) (Equation 6):

$$
\begin{gathered}
C R M=\frac{\sum_{I=1}^{n} O_{i}-\sum_{I=1}^{n} P_{i}}{\sum_{I=1}^{n} O_{i}} \\
\mathrm{CA}=\frac{\sum_{\mathrm{I}=1}^{\mathrm{n}}\left(\mathrm{O}_{\mathrm{i}}-\overline{\mathrm{O}}\right)^{2}}{\sum_{\mathrm{I}=1}^{\mathrm{n}}\left(\mathrm{P}_{\mathrm{i}}-\overline{\mathrm{O}}\right)^{2}}
\end{gathered}
$$

$$
E F=\frac{\sum_{I=1}^{n}\left(O_{i}-\bar{O}\right)^{2}-\sum_{I=1}^{n}\left(O_{i}-P_{i}\right)^{2}}{\sum_{I=1}^{n}\left(O_{i}-\bar{O}\right)^{2}}
$$

in which $\mathrm{O}_{\mathrm{i}}$ is the data observed; $\mathrm{P}_{\mathrm{i}}$, the data estimated by the respective models; $n$, the number of observations; and $\overline{\mathrm{O}}$, the arithmetic mean of the observations.

The CRM is a measure of the tendency of the model. If the value measured or observed approximates the value estimated by the model, the value of CRM draws near to zero. Positive and negative values of CRM indicate that the model underestimates and overestimates the measurements, respectively. The CA indicates the closeness of the values estimated to those observed. The EF value compares the simulated values with the mean value of the experimental measurements. The best fit of the model is found when the values of $\mathrm{R}^{2}, \mathrm{CA}$, and $\mathrm{EF}$ are near 1. A negative value for $\mathrm{EF}$ indicates that the mean value observed experimentally represents a better estimate for the variable than the estimated value.

\section{RESULTS AND DISCUSSION}

\section{Soil physical properties}

The values of soil bulk density and macroporosity were similar in the three tillage systems studied, considering the depth of 0.00-0.10 m (Table 1). In minimum tillage and no tillage, an increase was seen in the value of soil bulk density in the $0.10-0.20 \mathrm{~m}$ soil layer, while the values of macroporosity decreased in the three systems evaluated.

\section{Initial moisture, soil surface roughness and time to the beginning of surface runoff}

Soil moisture was similar among the treatments in the time prior to beginning application of simulated rainfall, which shows the efficiency of the pre-soaking performed (Table 2). Thus, the differences observed between the times of the beginning of surface runoff and of the water infiltration rate in the soil were due to the effect of the soil tillage practices adopted.

The greatest values of soil surface roughness and of the time of the beginning of runoff (Table 2) were observed in the MT treatment. These occurrences may be attributed to the effect of the shanks of the chisel plow, which promoted primary soil preparation, thus leading to changes in soil microrelief, creating clods and rupturing the deeper soil layers, favoring increase in the rate of water infiltration in the soil. The presence of these clods increases soil surface roughness, which increases the capacity of depressional storage of water 
on the surface, and thus reduces surface runoff. In the MT treatment, the value of soil surface roughness was approximately three times greater than the value in the CT treatment, and twice as great as the mean value of the treatments under NT. This tendency also occurred with the time of the beginning of surface runoff, promoting consideration of the importance of microrelief of the soil in containing surface runoff and, consequently, in limiting the process of erosion.

Among the treatments under NT, significant differences were not observed for the time of the beginning of surface runoff, observing, however, a tendency toward increase in the values of this variable as greater rates of common bean residue were used on the soil surface. In this case, it should be emphasized that the plant residues, although they did not provide greater soil surface roughness, were

Table 1. Soil bulk density, macroporosity, and total porosity in accordance with the treatments and depths sampled

\begin{tabular}{|c|c|c|c|}
\hline \multirow{2}{*}{ Depth } & \multicolumn{3}{|c|}{ Tillage system ${ }^{(1)}$} \\
\hline & MT & CT & NT \\
\hline & \multicolumn{3}{|c|}{ Soil bulk density $\left(\mathrm{kg} \mathrm{dm}^{-3}\right)$} \\
\hline $0.00-0.10 \mathrm{~m}$ & $1.40 \mathrm{Ab}$ & $1.38 \mathrm{Aa}$ & $1.44 \mathrm{Ab}$ \\
\hline \multirow[t]{2}{*}{$0.10-0.20 \mathrm{~m}$} & $1.56 \mathrm{Aa}$ & $1.42 \mathrm{Ba}$ & $1.63 \mathrm{Aa}$ \\
\hline & \multicolumn{3}{|c|}{ Macroporosity (\%) } \\
\hline $0.00-0.10 \mathrm{~m}$ & $18.52 \mathrm{Aa}$ & $21.12 \mathrm{Aa}$ & $15.36 \mathrm{Ba}$ \\
\hline \multirow[t]{2}{*}{$0.10-0.20 \mathrm{~m}$} & $13.10 \mathrm{Bb}$ & $16.76 \mathrm{Ab}$ & $8.59 \mathrm{Cb}$ \\
\hline & \multicolumn{3}{|c|}{ Total porosity (\%) } \\
\hline $0.00-0.10 \mathrm{~m}$ & $37.13 \mathrm{Ba}$ & $40.02 \mathrm{Aa}$ & $34.63 \mathrm{Ba}$ \\
\hline $0.10-0.20 \mathrm{~m}$ & $32.43 \mathrm{Bb}$ & $36.01 \mathrm{Ab}$ & $29.11 \mathrm{Cb}$ \\
\hline
\end{tabular}

effective in containing surface runoff through reducing the impact of the raindrops and exercising obstruction to water movement on the soil surface, just as reported by Hangen et al. (2002).

\section{Kinetic energy of the rain and the water infiltration rate in the soil}

The kinetic energy of the simulated rain was greatest in the minimum tillage system, arising from the greater interval of exposure to the effect of the impact of the raindrops (Table 3). The interval of exposure is the result of the sum of the time of the beginning of runoff and the time of $60 \mathrm{~min}$ in which the collections of runoff were made. This fact shows the importance of the effect of chisel plowing on reducing the torrent because even with greater time of exposure of the soil to the kinetic energy brought about by the impact of raindrops, greater water infiltration in the soil was seen under these conditions (Thierfelder et al., 2005).

The lowest rate of water infiltration in the soil at the beginning of surface runoff was found in the treatment NT0. The cause of this is associated with the low roughness of the soil surface and the absence of plant residues that would intercept the flow of the rain torrent (Table 2). In addition, in the treatments without soil tillage, a trend was found for a greater state of consolidation of the soil, with lower values of macroporosity (Table 1).

In the CT, the initial infiltration rate was similar to the rates observed in MT, NT3, NT6, and NT9. Nevertheless, in this treatment, there was a sharper reduction in the infiltration rate in the first $20 \mathrm{~min}$ after the beginning of surface runoff, just as verified by Nyamadzawo et al. (2007) and Silva (2007). This is due to soil mobilization promoted by CT operations which intensify the rupture of the aggregates by mechanical action. With the incidence of the impact of raindrops, the aggregates of smaller dimensions and the disaggregated particles obstruct the pores of the soil surface, which restricts infiltration (Zhang et al., 2007; Abid \& Lal, 2009).

Table 2. Mean values of initial soil moisture $(\theta i)$, random soil surface roughness $(R R)$, time to the beginning of surface runoff $\left(t_{\mathrm{o}}\right)$, kinetic energy of simulated rainfall (Ec) and of the rates of initial infiltration $\left(i_{o}\right)$ and final infiltration $\left(i_{f}\right)$

\begin{tabular}{|c|c|c|c|c|c|c|}
\hline & \multicolumn{6}{|c|}{ Tillage system ${ }^{(1)}$} \\
\hline & MT & $\mathrm{CT}$ & NT0 & NT3 & NT6 & NT9 \\
\hline$\theta \mathrm{i}\left(\mathrm{m} \mathrm{m}^{-1}\right)$ & $0.20 \mathrm{a}$ & $0.23 \mathrm{a}$ & $0.23 \mathrm{a}$ & $0.18 \mathrm{a}$ & $0.22 \mathrm{a}$ & $0.22 \mathrm{a}$ \\
\hline $\mathrm{RR}(\mathrm{mm})$ & $11.90 \mathrm{a}$ & $3.60 \mathrm{~b}$ & $5.40 \mathrm{~b}$ & $5.60 \mathrm{~b}$ & $6.20 \mathrm{~b}$ & $5.40 \mathrm{~b}$ \\
\hline$t_{\mathrm{o}}(\min )$ & $60.20 \mathrm{a}$ & $6.90 \mathrm{~b}$ & $7.30 \mathrm{~b}$ & $5.60 \mathrm{~b}$ & $13.10 \mathrm{~b}$ & $18.90 \mathrm{~b}$ \\
\hline Ec $\left(\mathrm{kJ} \mathrm{m}^{-2}\right)$ & $2.70 \mathrm{a}$ & $1.70 \mathrm{~b}$ & $1.70 \mathrm{~b}$ & $1.70 \mathrm{~b}$ & $1.90 \mathrm{~b}$ & $2.00 \mathrm{~b}$ \\
\hline$i_{o}\left(\mathrm{~mm} \mathrm{~h}^{-1}\right)$ & $58.40 \mathrm{a}$ & $56.00 \mathrm{ab}$ & $50.70 \mathrm{c}$ & $56.90 \mathrm{ab}$ & $52.50 \mathrm{bc}$ & $57.40 \mathrm{ab}$ \\
\hline$i_{f}\left(\mathrm{~mm} \mathrm{~h}^{-1}\right)$ & $54.00 \mathrm{a}$ & $16.90 \mathrm{~d}$ & $18.00 \mathrm{~d}$ & $16.60 \mathrm{~d}$ & $25.10 \mathrm{c}$ & $34.50 \mathrm{~b}$ \\
\hline
\end{tabular}

(1) MT: minimum tillage; CT: conventional tillage; NT0: no tillage without plant residue; NT3: no tillage with $3 \mathrm{Mg}^{-1}$ of plant residue; NT6: no tillage with $6 \mathrm{Mg} \mathrm{ha}^{-1}$ of plant residue; NT9: no tillage with $9 \mathrm{Mg} \mathrm{ha}^{-1}$ of plant residue. Mean values followed by the same lowercase letter in the same row do not differ among themselves at $5 \%$ by the Tukey test. 
The greatest value of the stable infiltration rate of water in the soil $\left(i_{f}\right)$ was found in the MT, followed by NT9 and NT6, respectively (Table 2). The MT was that which had the least reduction in the value of the water infiltration rate in the soil. At the end of the simulated rain test, it exhibited a reduction of $7.5 \%$ in relation to the initial value, while the treatments CT, NT0, NT3, NT6, and NT9 underwent reductions of $69,64,70,52$, and $40 \%$, respectively.

Although the CT treatment had the greatest values of macroporosity and the lowest values of soil bulk density (Table 1), the lowest stable infiltration rate of water in the soil was seen. This is due to the absence of soil cover and the action of the tillage operations that promote the rupture of the continuity of the pores, pulverization of the aggregates, and surface sealing. Rosa et al. (2013) reported that the occurrence of rain in a Hapludalf (Argissolo Vermelho-Amarelo) soil under conventional tillage, promotes greater degradation of the surface structure and greater thickness of the soil crust layer, in relation to reduced tillage and the absence of tillage.

In the case of the treatments under NT with a low quantity of common bean plant residue on the soil surface, the sharp reductions in the infiltration rate are possibly due to the effect of the impact of the raindrops, which acted so as to physically disperse the unstable aggregates present on the soil surface (Badorreck et al., 2013).

The treatments NT0 and NT3 did not differ from the CT and had $i_{f}$ values approximately $50 \%$ less than NT9. This shows the existence of a minimum value of plant residue for protection of the soil surface layer against the action of kinetic energy of the rain. Li et al. (2009) noted that with smaller quantities of plant residue, there is greater absorption of the kinetic energy of the rain by the soil surface and therefore, the stable infiltration rate of water in the soil decreases. Huang et al. (2013) concluded that the increase of plant cover on the soil surface favors infiltration and raises the recharge coefficient of water in the soil, contributing to water availability to plants.

In general, the $i_{f}$ values showed a trend similar to the values observed for soil surface roughness, corroborating the importance of this variable, especially under the conditions of absence or low quantity of plant residues on the soil surface. Therefore, it may be considered that the greatest value of $i_{f}$, found in the MT treatment, is due not only to the effect of the chisel plow shanks, but also to the increase in soil roughness, which provides greater time of contact between the water-soil interface, thus facilitating the infiltration process. The use of the chisel plow may be considered as an alternative for water conservation, with effects that may remain for a long time.

\section{Models for estimation of the infiltration rate of water in the soil}

Table 3 shows the $\alpha, \beta$, and $\mathrm{k}$ parameters, the statistical indices, and the coefficients of determination of the mathematical models of Kostiakov-Lewis, Horton, and Philip.

Analyzing the statistical coefficients CRM, CA, and $\mathrm{EF}$, it may be seen that, in general, the Horton

Table 3. Empirical parameters and statistical indices observed for the different treatments

\begin{tabular}{|c|c|c|c|c|c|c|}
\hline \multirow{2}{*}{ Parameter and statistical indice } & \multicolumn{6}{|c|}{ Tillage system ${ }^{(1)}$} \\
\hline & MT & CT & NT0 & NT3 & NT6 & NT9 \\
\hline & \multicolumn{6}{|c|}{ Kostiakov-Lewis Model } \\
\hline$\alpha$ & 0.22 & 0.51 & 0.50 & 0.50 & 0.34 & 0.49 \\
\hline $\mathrm{k}$ & 29.94 & 101.27 & 98.07 & 110.47 & 116.70 & 65.57 \\
\hline CRM & -0.01 & -0.02 & -0.02 & -0.04 & -0.02 & -0.01 \\
\hline $\mathrm{CA}$ & 3.45 & 1.56 & 1.66 & 2.05 & 1.96 & 1.91 \\
\hline \multirow[t]{2}{*}{$\mathrm{EF}$} & 0.71 & 0.36 & 0.40 & 0.51 & 0.49 & 0.48 \\
\hline & \multicolumn{6}{|c|}{ Horton Model } \\
\hline$\beta$ & 0.11 & 0.06 & 0.06 & 0.05 & 0.10 & 0.06 \\
\hline CRM & -0.01 & 0.00 & -0.01 & -0.01 & 0.01 & 0.00 \\
\hline $\mathrm{CA}$ & 2.64 & 1.06 & 1.08 & 1.60 & 1.53 & 1.44 \\
\hline \multirow[t]{2}{*}{$\mathrm{EF}$} & 0.62 & 0.06 & 0.08 & 0.37 & 0.35 & 0.31 \\
\hline & \multicolumn{6}{|c|}{ Philip Model } \\
\hline $\mathrm{k}$ & 17.56 & 113.70 & 108.83 & 126.89 & 91.86 & 72.59 \\
\hline CRM & 0.00 & 0.00 & 0.00 & 0.00 & 0.00 & 0.00 \\
\hline $\mathrm{CA}$ & 3.20 & 1.29 & 1.36 & 1.58 & 1.60 & 1.50 \\
\hline $\mathrm{EF}$ & 0.69 & 0.22 & 0.27 & 0.37 & 0.38 & 0.33 \\
\hline
\end{tabular}

(1) MT: minimum tillage; CT: conventional tillage; NT0: no tillage without plant residue; NT3: no tillage with $3 \mathrm{Mg}^{-1}$ of plant residue; NT6: no tillage with $6 \mathrm{Mg} \mathrm{ha}^{-1}$ of plant residue; NT9: no tillage with $9 \mathrm{Mg} \mathrm{ha}^{-1}$ of plant residue. 
model best fit the treatments studied, as also reported by Tomasini et al. (2010), evaluating water infiltration in a Latossolo Vermelho (Oxisol). Although the CRM values are near zero for the Horton and Philip models, it may be seen, in the case of Horton, that the CA values are nearer 1 and the EF values are nearer zero. Chahinian et al. (2005) found better fit of the Horton model than the Philip model under conditions of cultivated soil without tillage, subjected to simulated rain. In evaluation of the suitability of the models to the different soil tillage systems, the best fit was the Horton model for conventional tillage, with a $\mathrm{R}^{2}=0.93$. This is possibly due to the fact of soil turnover and exposure of the soil surface providing conditions favorable to direct impact of raindrops that promote surface sealing (Silva, 2007), which, according to this model, brings about reduction in the water infiltration rate in the soil.
The Kostiakov-Lewis model showed values of greater magnitude for the indices $\mathrm{CRM}$ and $\mathrm{EF}$, while those of CA were the ones most withdrawn from the unit. These characteristics indicate that the model is not suitable for the conditions of this study. It may furthermore be seen that this model was that which most overestimated the infiltration rate because the values of the CRM index were negative for all the treatments. The values estimated for the final infiltration rate went $42,35,40,12$, and $13 \%$ beyond those observed in the treatments CT, NT0, NT3, NT6, and NT9, respectively, while in the MT treatment it went beyond by less than $1 \%$.

In analysis of the curves of the infiltration rate corresponding to the data observed in the field and estimated by the models (Figure 1), it may be seen, in general, that the quality of the fit of the models was satisfactory, with the exception of the MT

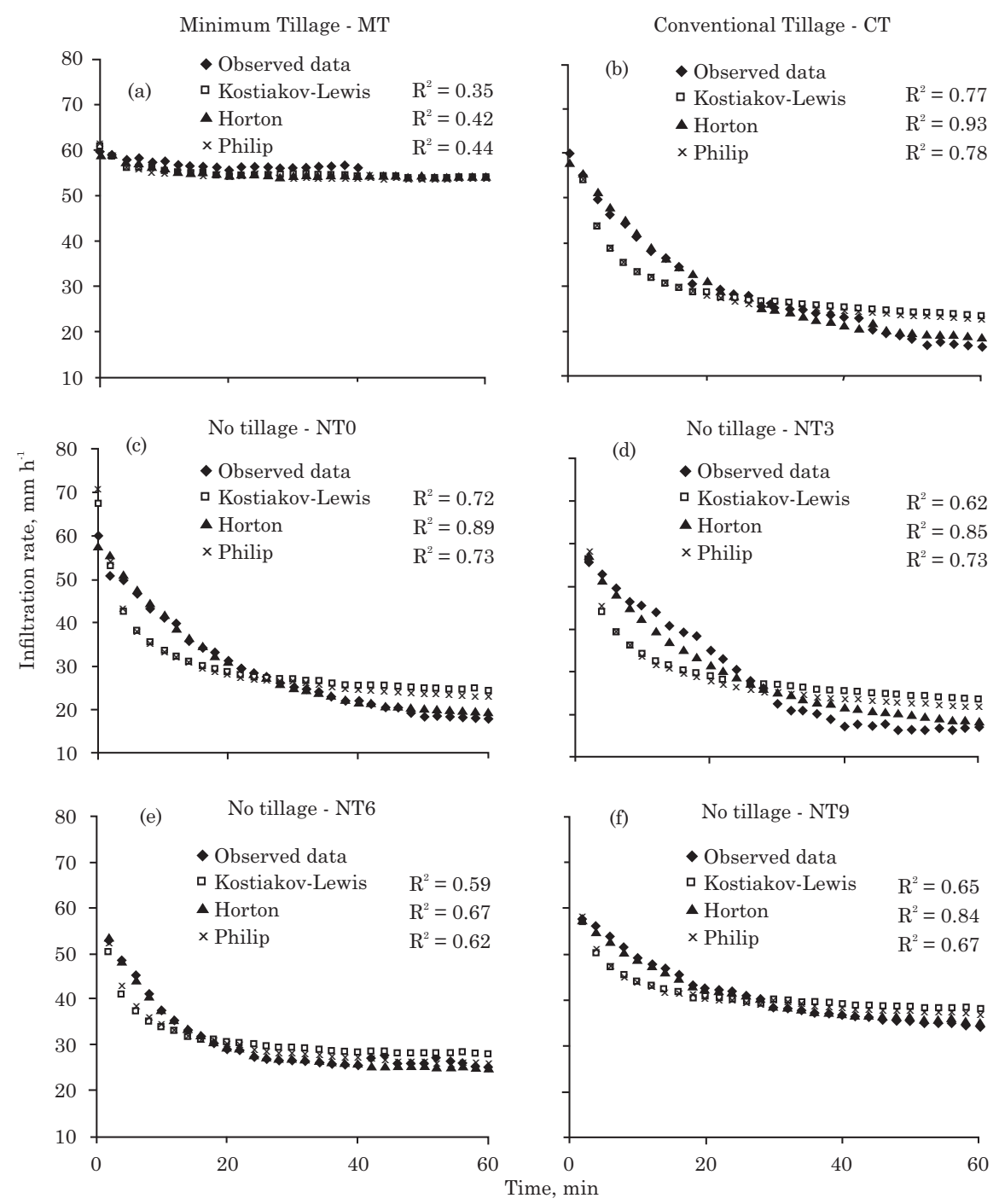

Figure 1. Infiltration rate observed and estimated based on the Kostiakov-Lewis, Horton, and Philip models for the treatments: (a) minimum tillage (MT); (b) conventional tillage (CT); (c) no tillage without plant residue (NT0); (d) no tillage with $3 \mathrm{Mg} \mathrm{ha}^{-1}$ of plant residue (NT3); (e) no tillage with $6 \mathrm{Mg} \mathrm{ha}^{-1}$ of plant residue (NT6); and (f) no tillage with $9 \mathrm{Mg} \mathrm{ha}^{-1}$ of plant residue (NT9). 
treatment, where the lowest values were observed for the coefficient of determination of the non-linear regressions. This is possibly due to the oscillations in the values of the infiltration rate observed during the application of simulated rain before reaching the value of $i_{f}$ (Figure 1a). Furthermore, in this treatment, a small variation was seen between the initial and final infiltration rate, corresponding to only $4.4 \mathrm{~mm} \mathrm{~h}^{-1}$ of difference, which may have contributed so that the fit of the models to the data was not consistent.

Upon studying the performance of some infiltration moUpon studying the performance of some infiltration models, Chahinian et al. (2005) concluded that in general performance, the Horton model proved to be more consistent than that of Philip. Panachuki et al. (2011), studied the effect of different management systems on water infiltration in a Latossolo Vermelho (Oxisol) and concluded that the Horton model allowed good fit of the data $\left(R^{2}=0.90\right)$. These results corroborate those found in this study.

\section{CONCLUSIONS}

1. Soil management systems that maintain soil cover on the surface or that alter the microrelief, such as through chisel plowing of the soil, have a favorable effect on reducing surface runoff of water and promoting an increase in the water infiltration rate.

2 . The infiltration rate is less in the conventional tillage system when compared to the conservationist systems. In minimum tillage, the final infiltration rate was $54 \mathrm{~mm} \mathrm{~h}^{-1}$, while in conventional tillage and no tillage with up to $3 \mathrm{Mg} \mathrm{ha}^{-1}$ of plant residue on the surface, the rate was near $17 \mathrm{~mm} \mathrm{~h}^{-1}$. In no tillage, increases were observed in the infiltration rate with plant residue cover greater than or equal to $6 \mathrm{Mg} \mathrm{ha}^{-1}$, showing a positive relationship between plant cover and the water infiltration rate.

3. The Horton model is the most suitable for representing the behavior of the water infiltration rate in the soil and may be recommended for estimating the infiltration rate regardless of the soil tillage system used. Nevertheless, the Philip model better fit the minimum tillage system.

\section{ACKNOWLEDGMENTS}

To the Fundação de Desenvolvimento do Ensino, Ciência e Tecnologia do Estado do Mato Grosso do Sul (Fundect) for financial support in developing the study and to the Coordenação de Aperfeiçoamento de Pessoal de Nível Superior (CAPES) for granting a Master's degree scholarship to the first author.

\section{LITERATURE CITED}

ABID, M. \& LAL, R. Tillage and drainage impact on soil quality: II. Tensile strength of aggregates, moisture retention and water infiltration. Soil Till. Res., 103:364-372, 2009.

AKAN, O. Horton infiltration equation revisited. J. Irrig. Drain. Eng., 118:828-830, 1992.

ALVES SOBRINHO, T.; CARVALHO, D.F.; AQUINO, R.M. \& MONTEBELLER, C.A. Software to estimate a rainfall cinetic energy simulated by rainfall infiltrometers. Eng. Rural, 12:28-35, 2001.

ALVES SOBRINHO, T.; MACPHERSON, H.G. \& GÓMEZ, J.A. A portable integrated rainfall and overland flow simulator. Soil Use Manage., 24:163-170, 2008.

AMERICAN SOCIETY OF AGRICULTURAL ENGINEERS ASAE. Terminology and definitions for soil tillage and soil tool relationships. St. Joseph, 1982. p.229-41. (ASAE EP291.1)

ASSOULINE, S. Infiltration into soil: Conceptual approaches and solutions. Water Resour. Res., 49:1-18, 2013.

BADORRECK, A.; GERK, H.H. \& HÜTTL, R.F. Morphology and physical soil crusts and infiltration patterns in an artificial catchment. Soil Till. Res., 129:1-8, 2013.

BERTOL, I.; AMARAL, A.J.; VAZQUEZ, E.V.; GONZALEZ, A.P.; BARBOSA, F.T. \& BRIGNONI, L.F. Relations of soil surface roughness with the rainfall volume and water aggregate stability. R. Bras. Ci. Solo, 30:543-553, 2006.

CARVAlHO, D.F.; MONTEBELlER, C.A.; CRUZ, E.S.; CEDDIA, M.B. \& LANA, A.M.Q. Soil and water losses in a Red Yellow Argissol under different intensities of simulated rainfall. R. Bras. Eng. Agríc. Amb., 6:385-389, 2002.

CHAHINIAN, N.; MOUSSA, R.; ANDRIEUX, P. \& VOLTZ, M. Comparison of infiltration models to simulated flood events at the field scale. J. Hidrol., 306:191-214, 2005.

COGO, N.P.; MOLDENHAUER, W.C. \& FOSTER, G.R. Soil loss reductions from conservation tillage practices. Soil Sci. Soc. Am. J., 48:368-373, 1984.

DALLMEYER, A.U. Eficiência energética e operacional de equipamentos conjugados de preparo de solo. Botucatu, Universidade Estadual Paulista, 1994. 157p. (Tese de Doutorado)

EMPRESA BRASILEIRA DE PESQUISA AGROPECUÁRIA EMBRAPA. Centro Nacional de Pesquisa de Solos. Manual de métodos de análise de solo. 2.ed. Rio de Janeiro, 1997. $212 \mathrm{p}$

HANGEN, E.; BUCZOKO, U.; BENS, O.; BRUNOTE, J. \& HÜTTL, R.F. Infiltration patterns into two soils under conventional and conservation tillage: Influence of the spatial distribution of plant root structures and soil animal activity. Soil Till. Res., 63:181-186, 2002.

HUANG, J.; WU, P. \& ZHAO, X. Effects of rainfall intensity, underlying surface and slope gradient on soil infiltration under simulated rainfall experiments. Catena, 104:93-102, 2013. 
KAMPHORST, E.C.; JETTEN, V.; GUÉRIF, J.; PITKANEN, J.; IVERSEN, N.V.; DOUGLAS, J.T. \& GONZÁLES, A.P. Predicting depressional storage from soil surface roughness. Soil Sci. Soc. Am. J., 64:1749-1758, 2000.

LIPIEC, J.; KUS, J.; SLOWINSKA-JURBIEWICS, A. \& NOSALEWICS, A. Soil porosity and water infiltration as influenced by tillage methods. Soil Till. Res., 89:210$220,2006$.

LI, Y.X.; TULLBERG, J.N.; FREBAIRN, D.M. \& LI, H.W. Functional relationships between soil water infiltration and wheeling and rainfall energy. Soil Till. Res., 104:156-163, 2009.

NYAMADZAWO, G.; CHIKOWO, R.; NYAMUGAFATA, P. \& GILLER, K.E. Improved legume tree fallows and tillage effects on structure stability and infiltration rates of a kaulinitic sandy soil from central Zimbabwe. Soil Till. Res., 92:182-194, 2007.

MBAGWU, J.S.C. Testing the goodness of fit of infiltration models for highly permeable soils under different tropical soil management systems. Soil Till. Res., 34:199205, 1995.

PANACHUKI, E.; ALVES SOBRINHO, T.; VITORINO, A.C.T.; CARVALHO, D.F. \& URCHEI, M.A. Evaluation of the infiltration rate in pasture-agriculture integration system, using a portable sprinkler infiltrometer. Acta Sci. Agron., 28:129-137, 2006.

PANACHUKI, E.; BERTOL, I.; ALVES SOBRINHO, T.; VITORINO, A.C.T.; SOUZA, C.M.A. \& URCHEI, M.A. Soil surface roughness under different management systems and artificial rainfall. R. Bras. Ci. Solo, 34:443451, 2010.

PANACHUKI, E.; BERTOL, I.; ALVES SOBRINHO, T.; OLIVEIRA, P.T.S. \& RODRIGUES, D.B.B. Soil and water loss and water infiltration in Red Latosol under different management systems. R. Bras. Ci. Solo, 35:1777-1786, 2011.
RAO, M.D.; RAGHUWANSKI, N.S. \& SINGH, R. Development of a physically based 1D-infiltration model for irrigated soils. Agric. Water Manage., 85:165-174, 2006.

ROSA, J.D.; COOPER, M.; DARBOUX, F. \& MEDEIROS, J.C. Influence of tillage systems and simulated rainfall on the process of surface crust formation. R. Bras. Ci. Solo, 37:400-410, 2013.

SILVA, L.L. Fitting infiltration equations to centre-pivot irrigation data in a Mediterranean soil. Agric. Water Manage., 94:83-92, 2007.

THIERFELDER, C.; COLLAZOS, E.A. \& STAHR, K. Effects of intensifying organic manuring and tillage practices on penetration resistance and infiltration rate. Soil Till. Res., 82:211-226, 2005.

TOMASINI, B.A.; VITORINO, A.C.T.; GARBIATE, M.V.; SOUZA, C.M.A. \& ALVES SOBRINHO, T. Water infiltration in soil cultivated with sugarcane: Under different cropping systems and models of adjustment of infiltration equations. Eng. Agric., 30:1060-1070, 2010.

VAHABI, J. \& NIKKAMI, D. Assessing dominant factors affecting soil erosion using a portable rainfall simulator. Int. J. Sedim. Res., 23:376-386, 2008.

WILlmotT, C.J.; ACKLESON, S.G.; DAVIS, R.E.; FEDDEMA, J.J.; KLINK, K.M.; LEGATES, D.R.; O'DONNELL, J. \& ROWE, C.M. Statistics for the evaluation and comparison of models. J. Geophys. Res., 90:8995-9005, 1985.

ZHANG, G.S.; CHAN, K.Y.; OATES, A.; HEENAN, D.P. \& HUANG, G.B. Relationship between soil structure and runoff/soil loss after 24 years of conservation tillage. Soil Till. Res., 92:122-128, 2007.

ZONTA, J.H.; MARTINEZ, M.A.; PRUSKI, F.F.; SILVA, D.D. \& SANTOS, M.R. Effect of successive rainfall with different patterns on soil water infiltration rate. R. Bras. Ci. Solo, 36:377-388, 2012. 